\title{
Noninvasive breath tests for diagnosis of SIBO and lactose intolerance in patients on chemotherapy treatment for colorectal and gastric cancer
}

\author{
Aline Rufino GONÇALVES, Orlando AMBROGINI JR and Nora Manoukian FORONES
}

Received: 19 June 2020 Accepted: 15 September 2020

\begin{abstract}
Background - Worldwide, colorectal cancer (CRC) and gastric cancer (GC) are the third and the fifth most prevalent, respectively. Diarrhea is a common symptom in patients on chemotherapy or radiotherapy treatment and can reduce treatment tolerance. Surgical resections and chemotherapy change the intestinal microbiota that can lead to lactose intolerance, small intestinal bacterial overgrowth (SIBO). Objective - The aim of the study was to evaluate the frequency of diarrhea in patients with CRC and GC on chemotherapy with SIBO or intolerance of lactose. Methods - This is a descriptive and observational study with patients of both sexes, over 18 years old, in treatment in the Gastro-Oncology outpatient clinic of the Federal University of São Paulo. Patients with a confirmed diagnosis of CRC or GC during chemotherapy treatment were included. To detect bacterial overgrowth and lactose intolerance, breath hydrogen test with lactulose and lactose was done. Number and aspects of the evacuations and toxicity degree were collected. For the nutritional assessment, weight and height were performed to calculate the BMI. and the Patient Generated Subjective Global Assessment (PG-SGA). Results - A total of 33 patients were included, 29 with CRC and 3 with GC. Most of them were male (57.57\%), mean age of $60.03 \pm 10.01$ years and in chemotherapy with fluoropyrimidine and oxaliplatin (54.5\%). Diarrhea was present in $57.6 \%$ and $30.3 \%$ had toxicity grade 2. According to the BMI, 78.9\% were eutrophics, obese or overweight, but according to PG-SGA, $84.9 \%$ had moderate or severe nutritional risk grade. Between patients, $45 \%$ had lactose intolerance and 9\% SIBO. Diarrhea grade 2-3 was observed in $66.6 \%$ of patients with SIBO and $66.7 \%$ of that with lactose intolerance. No statistical difference was observed between patients with SIBO or lactose intolerance and grade of diarrhea. Conclusion - Diarrhea was a frequent symptom in chemotherapy patients with gastric or colorectal cancer independent of the presence of SIBO or lactose intolerance. Surgery and chemotherapy treatment impacted in the intestinal habit of patients. Diagnosis of other causes of diarrhea may contribute to a better tolerance to treatment and quality of life.
\end{abstract}

HEADINGS - Colorectal neoplasms, drug therapy. Stomach neoplasms, drug therapy. Diarrhea. Bacteria, growth \& development. Lactose intolerance.

\section{INTRODUCTION}

According to Globocan, in 2018, there were more than 1.8 million new cases of colorectal cancer (CRC) with 881 thousand deaths and 1.0 million new cases of gastric cancer (GC) with 783 thousand deaths, worldwide. In Brazil, 41.000 new cases of CRC and 21.000 new cases of GC had been estimated each year for the 2020-2022 period $^{(1,2)}$.

The prognosis depends mainly on the pathological stage. The treatment (surgical resection, adjuvant or neoadjuvant chemotherapy and radiotherapy) have an important influence on prognosis but also may cause pain, constipation or diarrhea, nausea, vomiting, lack of appetite, contributing to the reduction of food intake and consequent malnutrition ${ }^{(3,4)}$.

Diarrhea is a common symptom in patients on chemotherapy or radiotherapy treatment ${ }^{(5)}$. Treatment-related diarrhea is a very common toxicity, which can reduce treatment tolerance ${ }^{(6)}$. Longterm changes in bowel function after cancer treatment are common and can decrease the patient's quality of life ${ }^{(7)}$. Between $15 \%$ to $66 \%$ of cancer patients treated with surgery, radiation and chemotherapy suffer from chronic gastrointestinal symptoms ${ }^{(8)}$.
Despite these kinds of treatments, diarrhea may be caused by others factors as intestinal bacterial disorders, known as small intestinal bacterial overgrowth (SIBO) or intolerance to lactose.

Surgical resection of the gastrointestinal tract and chemotherapy can lead to malnutrition that is correlated with poor prognosis and intolerance to chemotherapy treatment. Body mass index (BMI) is an easy, lower cost and fast method to diagnose malnutrition, however it does not evaluate loss of weight during the last months ${ }^{(9)}$. The PatientGenerated Subjective Global Assessment (PG-SGA), is a subjective, noninvasive method that can detect individuals at nutritional risk, with sensibility and specificity of the $98 \%$ and $82 \%$, respectively. This tool can identify early patients with risk of malnutrition who will benefit from specialized nutritional intervention ${ }^{(9,10)}$.

SIBO is defined by the abnormal and excessive presence of the number of bacteria in the small intestine and is associated with a group of clinical symptoms, such as abdominal distention, flatulence, abdominal pain, nausea, dyspepsia, fatigue, diarrhea and constipation ${ }^{(11)}$. Alterations of the defense mechanisms of the gastrointestinal tract, such as gastric acid secretion, motility and integrity of the intestinal mucosa may cause the disease. More than $40 \%$ of patients undergoing subtotal colectomy with resection of 
the ileocecal valve report persistent gastrointestinal symptoms, suggesting that it may predispose to $\mathrm{SIBO}^{(12)}$. This disease may occur in patients during radiotherapy or chemotherapy ${ }^{(13)}$.

Clinical studies suggest that bacterial overgrowth of the small intestine, malabsorption of bile acids and pancreatic insufficiency are factors that can increase chemotherapy-induced symptoms in gastrointestinal tract.

Lactose intolerance is a pathological condition characterized by abdominal symptoms caused by lactase deficiency enzyme caused by polymorphisms in the MCM6 gene. These polymorphisms can be different according to the region ${ }^{(14)}$. Humans born with initially elevated levels of lactase in intestinal enterocytes that decrease in adults $^{(14)}$. The expression of lactase is decreased in approximately $2 / 3$ of the world population, leading to lactose intolerance.

During chemotherapy, there is an increase in transit and changes in the intestinal flora, which can also lead to lactose intolerance and malabsorption of bile acids ${ }^{(15,16)}$.

The aim of the study was to evaluate the frequency of diarrhea among patients with CRC and GC on chemotherapy and SIBO or intolerance of lactose.

\section{METHODS}

This is a descriptive and observational study with patients of both sexes, over 18 years old, in treatment in the Gastro-Oncology and Clinical Oncology outpatient clinic of the Federal University of São Paulo. The study was submitted to the Local Ethics Committee and was approved under CAAE n. 81597517.0.0000.5505. All the patients were informed and signed the informed consent form.

Patients with a confirmed diagnosis of colorectal or gastric cancer during chemotherapy were included. Subjects with other types of neoplasia were excluded.

For the construction of an excel spreadsheet, age, sex, histological type of the tumor and its stage, presence of diarrhea, number of bowel movements, degree of toxicity according to the Common Terminology Criteria for Adverse Events (CTCAE) ${ }^{(17)}$ and aspect of them according to the Bristol ${ }^{(18)}$ scale were collected.

To assess the degree of toxicity of diarrhea (Grade 1-5), the CTCAE $^{(17)}$ was used. In addition to the CTCAE, the Bristol Scale ${ }^{(18)}$, proposed by Lewis and Heaton, was used, which is a medical scale designed to categorize shape of human stools.

\section{Breath noninvasive test}

Small intestinal bacterial overgrowth and lactose intolerance were done in the laboratory of breath tests of the Hospital São Paulo, in fasting patients in chemotherapy treatment. During the last 24 hours a special diet without fibers or food with fermentative effect was done. They were instructed to do a good oral hygiene and not smoke for 4 hours before the test. Using a disposable gas mouth blowpipe, the patient investigated subject exhaled slowly for as long as possible. The first exhalation was done at the beginning and after an ingestion of a liquid sweetened with lactulose or lactose for the test of SIBO or lactose intolerance respectively at repeated intervals of 20 minutes for a total of 150 minutes. Up to 90 minutes values $\geq 20$ PPM were considered positive for bacterial overgrowth. Some patients had a second elevation after $90 \mathrm{~min}$ that had also measured. The breath exams were done in different days ${ }^{(19)}$. Lactose intolerance is an elevation $\geq 20$ PPM at any time during the test (values of $\geq 20$ PPM and $<70$ PPM is considered low grade intolerance and values $>70$ PPM are considered high grade intolerance).

\section{Nutritional assessment and nutrition risk}

For the nutritional assessment, weight and height were collected to calculate the BMI. Its classification was carried out according to the World Health Organization for adults ${ }^{(20)}$ and Lipschitz ${ }^{(21)}$ for elderly patients. Before the expired hydrogen test, all patients answered the PG-SGA.

\section{Statistical analysis}

Exploratory data analysis included mean, median, standard deviation and variation for continuous variables and number and proportion for categorical variables. Comparison of the mean age between the two groups was made using the $t$-Student. Comparison of categorical variables between the two groups was performed using Fischer's exact test. Statistical analysis was performed using the software IBM-SPSS Statistics version 24 (IBM Corporation, NY, USA). Two tailed testes were done and values of $P<0.05$ were considered significant.

\section{RESULTS}

Fifty-four patients were selected, but only 33 patients were included. The others were excluded because they had already finished the chemotherapy or dropped out of the study. The majority were male $(57.6 \%)$ and the mean age was $60.03( \pm 10.1)$ years. Thirty patients had CRC and $3 \mathrm{GC}$. Thirty-two patients performed breath test with lactulose and 20 with lactose.

According to the BMI, $26(78.9 \%)$ had eutrophic, obese or overweight, and only seven had malnutrition. However, the PGSGA showed that $28(84.9 \%$ ) had nutritional moderate risk (grade B) or severe risk (grade C) (TABLE 1). Most of the patients had adenocarcinoma ( $88 \%$ ), three had neuroendocrine tumor and one gastrointestinal stromal tumor.

SIBO was positive in $3 / 32(9.1 \%)$ patients and lactose intolerance in $9 / 20(45 \%)$ patients, all with low grade (TABLE 2). None of them had SIBO and lactose intolerance. Nineteen $(57.6 \%)$ had diarrhea, being grade $2 / 3$ in $13(39.4 \%)$. Most of the patients were on chemotherapy with 5-fluorouracil/capecitabine and oxaliplatin $(54.5 \%)$ or 5 fluorouracil / capecitabine $(33.2 \%)$. 5Fluorouracil $(5 \mathrm{FU})$ and capecitabine are fluoropyrimidines used intravenous and oral, respectively.

In the comparative analysis of patients with or without SIBO, no significant differences were detected in terms of gender or age (TABLE 3). Diarrhea toxicity according to CTCAE among patients with and without SIBO was analyzed; the grades $2 / 3$ were observed in $2 / 3(66.6 \%)$ of the patients with SIBO. According to Bristol's scale, $66.6 \%$ of the patients presented grade 5-7.

Lactose intolerance also had no significant difference between genders or age (TABLE 4). The proportions were similar for elderly between groups. No difference was observed between the chemotherapy treatments and lactose intolerance. According to Bristol's scale $77.8 \%$ of the patients with lactose intolerance presented grade 5-7. Two patients had high grade intolerance of lactose with values >70 PPM and Bristol scale 6 and 7. Although the difference between the grade of toxicity of diarrhea or the Bristol scale was not statistically significant, patients with SIBO or lactose intolerance had a higher percentual of patients with diarrhea grade 2/3 and Bristol scale of 5-7. 
TABLE 1. Sociodemographic and clinical data of patients included in the study.

\begin{tabular}{lc}
\hline Variable & $\mathbf{N}=33$ \\
\hline Age, years & $60.03 \pm 10.1$ \\
Age range, n (\%) & \\
Adults (19-59 years) & $13(39.4)$ \\
Elderly ( $\geq 60$ years) & $20(60.6)$ \\
Gender, n (\%) & \\
Male & $19(57.6)$ \\
Female & $14(42.4)$ \\
Tumor Location, n (\%) & \\
Rectum & $16(48.5)$ \\
Right Colon & $7(21.1)$ \\
Left Colon & $7(21.1)$ \\
Stomach & $3(9.1)$ \\
Nutritional status (BMI) n (\%) & \\
Malnutrition & $7(21.1)$ \\
Eutrophy & $15(45.5)$ \\
Overweight & $5(15.2)$ \\
Obesity I & $6(18.2)$ \\
Nutritional risk (PG-SGA) (n \%) & \\
A & $5(15.2)$ \\
B & $15(45.5)$ \\
C & $13(39.4)$ \\
\hline
\end{tabular}

Continuous variables are described as mean \pm standard-deviation; categorical variables are described in number (percentage). BMI: body mass index; PG-SGA: Patient GeneratedSubjective Global Assessment.

TABLE 2. Distribution of the patients according to diarrhea, chemotherapy, or target drugs treatment, SIBO and lactose intolerance.

\begin{tabular}{lc}
\hline Characteristic & $\mathbf{N}=33$ \\
$\mathbf{N}(\%)$
\end{tabular}

SIBO: small intestinal bacterial overgrowth; RT: radiotherapy.
TABLE 3. Descriptive and comparative analysis of SIBO, according to demographic and clinical data of patients.

\begin{tabular}{|c|c|c|c|}
\hline & \multicolumn{2}{|c|}{ SIBO } & \multirow{2}{*}{$\frac{\mathrm{I}}{P \text { value }}$} \\
\hline & $\begin{array}{c}\text { Negative } \\
(\mathrm{n}=29)\end{array}$ & $\begin{array}{c}\text { Positive } \\
(\mathrm{n}=3)\end{array}$ & \\
\hline \multicolumn{4}{|l|}{ Gender } \\
\hline Male & $18(62.1)$ & $0(0)$ & \multirow{2}{*}{0.07} \\
\hline Female & $11(37.9)$ & $3(100)$ & \\
\hline Age, years & $63.07 \pm 10.2$ & $65.67 \pm 11.0$ & 0.68 \\
\hline \multicolumn{4}{|l|}{ Age range } \\
\hline Adults (19-59 years) & $11(37.9)$ & $1(33.3)$ & \multirow{2}{*}{1.000} \\
\hline Elderly ( $\geq 60$ years) & $18(62.1)$ & $2(66.7)$ & \\
\hline \multicolumn{4}{|l|}{ Tumor location, n (\%) } \\
\hline Colorectal cancer & $26(89.7)$ & $3(100)$ & \multirow{2}{*}{-} \\
\hline Gastric cancer & $3(10.3)$ & $0(0)$ & \\
\hline \multicolumn{4}{|l|}{ Histological type, n (\%) } \\
\hline Adenocarcinoma & $25(86.2)$ & $3(100)$ & \multirow{2}{*}{1.00} \\
\hline NET/GIST & $4(13.7)$ & 0 & \\
\hline \multicolumn{4}{|c|}{ Diarrhea toxicity (CTCAE), n (\%) } \\
\hline Grade $0-1$ & $13(44.8)$ & $1(33.3)$ & \multirow{2}{*}{1.00} \\
\hline Grade $2-3$ & $16(55.2)$ & $2(66.6)$ & \\
\hline
\end{tabular}

Bristol's scale

$\begin{array}{cccc}1-3 & 3(10.3) & 0 & \\ 4-7 & 26(89.6) & 3(100) & 1.00\end{array}$

Surgical procedure, $\mathrm{n}(\%)$

$\begin{array}{lcc}\text { Intestinal surgery } & 22(75.8) & 1(33.3) \\ \text { Gastric surgery } & 2(6.9) & 0 \\ \text { No surgery } & 5(17.2) & 2(66.7)\end{array}$

Chemotherapy with 5FU/oxaliplatin, n (\%)

$\begin{array}{lll}\text { Yes } & 17(58.62) & 1(33.3)\end{array}$

No $12(41.38) \quad 2(66.7)$

0.57

*Chemotherapy with capecitabine/5FU, n (\%)

$\begin{array}{lll}\text { Yes } & 9(31.03) & 2(66.7)\end{array}$

$\begin{array}{lll}\text { No } & 20(68.96) \quad 1(33.3)\end{array}$

Nutritional status (BMI), n (\%)

\begin{tabular}{|c|c|c|}
\hline Malnutrition & $6(20.7)$ & $1(33.3)$ \\
\hline $\begin{array}{l}\text { Eutrophy/overweight/ } \\
\text { obesityI }\end{array}$ & $23(79.3)$ & $2(66.7)$ \\
\hline \multicolumn{3}{|c|}{ Nutritional risk (PG-SGA), n (\%) } \\
\hline $\mathrm{A} / \mathrm{B}$ & $18(62.1)$ & $2(66.6)$ \\
\hline $\mathrm{C}$ & $11(37.9)$ & $1(33.3)$ \\
\hline
\end{tabular}

Continuous variables are described as mean \pm standard-deviation; categorical variables are described in number (percentage). CTCAE: Common Terminology Criteria for Adverse Events; 5FU:5-Fluorouracil; SIBO: Small Intestinal Bacterial Overgrowth; NET: neuroendocrine tumor; GIST: gastrointestinal stromal tumor; BMI: body mass index; PG-SGA: Patient GeneratedSubjective Global Assessment. *With or without radiotherapy. 
TABLE 4. Descriptive and comparative analysis of lactose intolerance, according to patients' demographic and clinical data.

\begin{tabular}{|c|c|c|c|}
\hline & \multicolumn{2}{|c|}{ Lactose intolerance } & \multirow[b]{2}{*}{$P$ value } \\
\hline & $\begin{array}{c}\text { Negative } \\
(\mathrm{n}=11)\end{array}$ & $\begin{array}{c}\text { Positive } \\
(\mathrm{n}=9)\end{array}$ & \\
\hline \multicolumn{4}{|l|}{ Gender, n (\%) } \\
\hline Male & $6(54.5)$ & $7(77.8)$ & \multirow{2}{*}{0.37} \\
\hline Female & $5(45.4)$ & $2(22.2)$ & \\
\hline Age, years & $64.3 \pm 12.9$ & $61.9 \pm 8.5$ & 0.64 \\
\hline \multicolumn{4}{|l|}{ Age range } \\
\hline Adults (19-59 years) & $4(36.3)$ & $3(33.3)$ & \multirow{2}{*}{1.00} \\
\hline Elderly ( $\geq 60$ years) & $7(63.6)$ & $6(66.7)$ & \\
\hline \multicolumn{4}{|l|}{ Tumor location, n (\%) } \\
\hline Colorectal cancer & $10(90.9)$ & $7(77.8)$ & \multirow[b]{2}{*}{-} \\
\hline Gastric cancer & $1(9.1)$ & $2(2.2)$ & \\
\hline \multicolumn{4}{|l|}{ Histological type, n (\%) } \\
\hline Adenocarcinoma & $10(90.9)$ & $8(89)$ & \multirow{2}{*}{1.00} \\
\hline NET/GIST & $1(9.1)$ & $1(11.1)$ & \\
\hline \multicolumn{4}{|l|}{ Diarrhea toxicity (CTCAE), n (\%) } \\
\hline Gade 0-1 & $6(54.6)$ & $3(33.3)$ & \multirow{2}{*}{0.66} \\
\hline Grade $2-3$ & $5(45.4)$ & $6(66.7)$ & \\
\hline \multicolumn{4}{|l|}{ Bristol's scale n (\%) } \\
\hline $1-3$ & $1(9.1)$ & $1(11)$ & \multirow[b]{2}{*}{1.00} \\
\hline $4-7$ & $10(90.9)$ & $8(89)$ & \\
\hline \multicolumn{4}{|l|}{ Surgical procedure, n (\%) } \\
\hline Intestinal surgery & $9(81.2)$ & $5(55.5)$ & \multirow{3}{*}{-} \\
\hline Gastric surgery & $1(9.1)$ & $2(22.2)$ & \\
\hline No surgery & $1(9.1)$ & $2(22.2)$ & \\
\hline \multicolumn{4}{|c|}{ Chemotherapy with 5FU/oxaliplatin, n (\%) } \\
\hline Yes & $8(72.7)$ & $2(22.2)$ & \multirow{2}{*}{0.17} \\
\hline No & $3(27.3)$ & $7(77.8)$ & \\
\hline \multicolumn{4}{|c|}{ *Chemotherapy with capecitabine/5FU, n (\%) } \\
\hline Yes & $1(9.1)$ & $6(66.7)$ & \multirow{2}{*}{1.00} \\
\hline No & $10(90.9)$ & $3(33.3)$ & \\
\hline \multicolumn{4}{|l|}{ Nutritional status (BMI), n (\%) } \\
\hline Malnutrition & $3(27.3)$ & $2(22.2)$ & \multirow{2}{*}{1.00} \\
\hline Eutrophy/overweight/obesity I & $8(72.7)$ & $7(77.8)$ & \\
\hline \multicolumn{4}{|l|}{ Nutritional risk (PG-SGA), n (\%) } \\
\hline $\mathrm{A} / \mathrm{B}$ & $6(54.5)$ & $7(77.8)$ & \multirow{2}{*}{0.37} \\
\hline $\mathrm{C}$ & $5(45.5)$ & $2(22.2)$ & \\
\hline
\end{tabular}

Continuous variables are described as mean \pm standard-deviation; Categorical variables are described in number (percentage). CTCAE: Common Terminology Criteria for Adverse Events; 5FU: 5-Fluorouracil; NET: neuroendocrine tumor; GIST: gastrointestinal stromal tumor; BMI: body mass index; PG-SGA: Patient Generated-Subjective Global Assessment. *With or without radiotherapy.

\section{DISCUSSION}

Diarrhea is a common side effect during chemotherapy and is usually attributed to the toxicity of the drugs. In our study, $57.6 \%$ of the patients presented diarrhea.

Schmoll et al. ${ }^{(22)}$, published in a large study that patients with CRC stage III treated with adjuvant chemotherapy (capecitabine and oxaliplatin or 5FU) had diarrhea in $60-68 \%$ being severe in $20 \%$ (grade 3 or 4). When associated to radiotherapy, this risk increases $21 \%{ }^{(23)}$. In our study, $66.6 \%$ of the patients with SIBO and $77.8 \%$ with lactose intolerance had diarrhea.
Decrease concentration of acid by surgical resection of the stomach or chronic use of inhibitor of protonic pump, immunodeficiency, surgery with transit deviation and resection of the ileum cecal valve with reflux of the bacteria from the colon and decrease of the motility of the intestine can induce SIBO. Bacterial overgrowth causes diarrhea because the enzymes of the bacteria compete with the enzymes of the digestive wall.

SIBO can be detected by noninvasive breath tests with glucose or lactulose. However, there is no consensus about which one is better glucose or lactose. Lactulose is an osmotic sugar that can accelerate the intestinal transit and the diagnosis can reproduce colonic bacteria increasing the number of false positive. In the other hand glucose can be absorbed fast and did not show bacteria on the ileum (increasing the number of false negative).

Losurdo et al. ${ }^{(18)}$, described in a metanalysis that glucose had a sensitivity of $54.5 \%$ and a specificity of $83.2 \%$ and lactulose had a sensitivity of $42 \%$ and a specificity of $70.6 \%$.

In our study among the 32 patients, two patients with SIBO had not performed surgery and one performed intestinal resection. Rao et al reported that prevalence of SIBO in patients with unexplained abdominal pain, gas, bloating and diarrhea was twice $(62 \%)$ in patients that performed colectomy compared to the control group without colectomy (32\%). They described that the intestinal flora was different between the groups, with predominance of aerobic bacteria and less anaerobic microorganisms in patients with SIBO post-colectomy ${ }^{(11)}$.

Brägelmann et al., described that in 80 patients with GC submitted to gastrectomy, $63 \%$ had SIBO with abdominal distension in $71 \%$, without significant changes in other characteristics, including nutritional status according to $\mathrm{BMI}^{(24)}$. Newberry et al., also did not correlate SIBO with malnutrition by $\mathrm{BMI}^{(25)}$. In our study, we did not find significant difference between nutritional status in patients with SIBO.

Saffouri et al., compared the presence of SIBO by quantitative duodenal aspirate to the presence of diarrhea, abdominal pain and bloating and did not find a positive correlation between symptoms and $\mathrm{SIBO}^{(26)}$. In our study, between the three patients with SIBO in chemotherapy, two had diarrhea grade $2 / 3$ and Bristol scale 5-7.

The study of Liang evaluated 112 patients with GC and 88 with CRC and observed that $73(65.2 \%)$ patients with GC and 53 (60.2\%) with CRC presented SIBO studied by glucose-H2-breath test (GHBT) ${ }^{(27)}$. In our study, we evaluated 30 patients with CRC and three with GC, but only three patients with CRC had SIBO by lactulose $\mathrm{H} 2$ breath test.

Osterlund et al., performed a study with 150 patients with CRC, treated with 5-FU and leucovorin, 24\% presented hypolactasia before chemotherapy and $35 \%$ during the treatment. In general, $94 \%$ of the patients presented symptoms compatible with lactose intolerance. Seventy-six per cent of them had diarrhea grade 0-2 and $24 \%$ grade $3-4^{(28)}$. In our study, lactose intolerance was diagnosed in $45 \%$ of the patients, $66.7 \%$ of them had diarrhea, being Bristol's scale 5-7 in 77.8\%.

Regarding to the nutritional status, Osterlund et al. ${ }^{(28)}$, described that $71 \%$ were well nourished, according to SGA. In our study, most of the patients had not malnutrition according to the BMI. Considering the PG-SGA, two patients with SIBO had moderate or severe nutrition risk. Regarding the patients with lactose intolerance, $22.2 \%$ presented severe risk of nutrition.

The small number of patients included was a limitation of the study. Many patients did not accept to do both breath tests 
during the chemotherapy treatment. We believe that this difficulty was a consequence of the patients' extensive routine procedures as medical consultations, chemotherapy days, routine blood, and imaging exams, beyond the treatment side toxicity such as fatigue, nausea, and diarrhea. Another limitation was the choice of a breath test in the diagnosis of SIBO. The gold standard for the diagnosis of this disease is the culture of jejunal aspiration, that is an invasive and expensive exam, not routinely done in our country. However, it was interesting to demonstrate that these patients had others causes of diarrhea that can explain or intensify the diarrhea of patients on chemotherapy and gastrointestinal or colorectal cancer.

In conclusion more than half of the patients on chemotherapy with gastrointestinal cancer had diarrhea. Nine per cent of the patients had SIBO and $45 \%$ had lactose intolerance. Regarding the nutritional status, most of the patients had eutrophic, overweight or obesity by the BMI independent of the presence of SIBO or intolerance of lactose. According to PG-SGA, moderate or severe nutritional risk was present in a high percent of the patients.
Although we did not find correlation between SIBO or lactose intolerance and intensity or characteristic of the stools, the diagnosis of other causes of diarrhea can contribute to a specific treatment with better tolerance to chemotherapy and better quality of life.

\section{Authors' contribution}

Gonçalves AR did the inclusion of the patients, performance of the breath tests with the laboratory technicians, statistical analysis and writing the article. Ambrogini Jr O. contributed to the interpretation of the breath tests and the concept of the study. Forones NM contributed to the concept, design and the finalization of the manuscript.

\section{Orcid}

Aline Rufino Gonçalves: 0000-0003-4313-7704.

Orlando Ambrogini Jr: 0000-0003-3318-6246.

Nora Manoukian Forones: 0000-0001-9414-0343.

Gonçalves AR, Ambrogini Jr O, Forones NM. Testes respiratórios não invasivos para o diagnóstico de SBID e intolerância à lactose em pacientes com câncer colorretal e gástrico em tratamento quimioterápico. Arq Gastroenterol. 2021;58(1):26-31.

RESUMO - Contexto - Mundialmente, o câncer colorretal (CCR) e gástrico (CG) são a terceira e a quinta causa de câncer mais prevalente, respectivamente. A diarreia é um sintoma comum entre os pacientes em quimioterapia ou radioterapia e pode reduzir a tolerância ao tratamento. Quimioterapia e ressecções cirúrgicas causam alterações da microbiota intestinal que podem levar a intolerância à lactose e ao supercrescimento bacteriano do intestino delgado (SBID). Objetivo - Avaliar a presença de diarreia nos pacientes com câncer colorretal e gástrico em quimioterapia e a presença de SBID ou intolerância à lactose. Métodos - Foi realizado um estudo descritivo, observacional com pacientes ambulatoriais de ambos os sexos, maiores de 18 anos, em tratamento no ambulatório de gastro-oncologia da Universidade Federal de São Paulo. Foram incluídos pacientes com diagnóstico confirmado de CCR ou CG durante tratamento quimioterápico. Para detectar supercrescimento bacteriano e intolerância à lactose, foram realizados testes respiratórios com lactulose e lactose respectivamente. Número, aspecto das evacuações e grau de toxicidade foram coletados. Para a avaliação nutricional foram aferidos peso e altura para cálculo do IMC e para avaliação do risco nutricional foi realizada a avaliação subjetiva global produzida pelo próprio paciente (ASG-PPP). Resultados - Foram incluídos 33 pacientes, 29 com CCR e 3 com CG. A maioria era do sexo masculino (57,5\%)

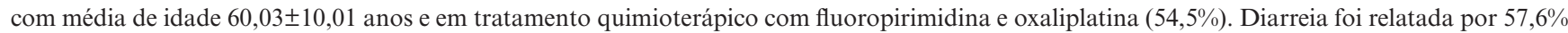
dos pacientes sendo em 30\% grau 2. Pelo IMC, 78,9\% apresentavam eutrofia, sobrepeso ou obesidade grau 1, mas pela ASG-PPP 84,9 apresentavam risco nutricional moderado ou severo. Entre os pacientes 9\% apresentavam SBID e 45\% intolerância à lactose. Diarreia grau 2-3 foi observada em 66,6\% daqueles pacientes com SBID e 66,7\% dos com intolerância à lactose. Não encontramos diferenças estatísticas entre os pacientes com SBID ou intolerância à lactose e intensidade de diarreia. Conclusão - Diarreia foi um sintoma frequente entre os pacientes com câncer gástrico ou colorretal em quimioterapia independente da presença de SBID ou intolerância à lactose. Cirurgia e quimioterapia impactaram no hábito intestinal dos pacientes. O diagnóstico de outras causas de diarreia pode contribuir para a melhor tolerância do tratamento e qualidade de vida.

DESCRITORES - Neoplasias colorretais, tratamento farmacológico. Neoplasias gástricas, tratamento farmacológico. Diarreia. Bactéria, crescimento \& desenvolvimento. Intolerância à lactose.

\section{REFERENCES}

1. Bray F, Ferlay J, Soerjomataram I, Siegel RL, Torre LA, Jemal A. Global Cancer Statistics 2018: GLOBOCAN Estimates of Incidence and Mortality Worldwide for 36 Cancers in 185 Countries. CA: Cancer J Clin. 2018;68:394-424.

2. Instituto Nacional do Câncer. Incidência de Câncer no Brasil Estimativa 2020 [Internet]. [Acessed 2020 March 25]. Available from: https://www.inca.gov.br/ publicacoes/livros/estimativa-2020-incidencia-de-cancer-no-brasil.

3. Holmes AC, Riis AH, Erichsen R, Fedirko V, Ostenfeld EB, Vyberg M et al. Descriptive Characteristics of Colon and Rectal Cancer Recurrence in Danish Population Based-Study. Acta Oncologica. 2017;56:1111-9.

4. Carlotto A, Hogsett VL, Maiorini EM, Razulis JG, Sonis ST. The economic burden of toxicities associated with cancer treatment: review of the literature and analysis of nausea and vomiting, diarrhea, oral mucositis and fatigue. Pharmacoeconomics. 2013;31:753-66.
5. Andreyev J, Ross P, Donnellan C, Lennan E, Leonard P, Waters C, Wedlake L et al., Guidance on the management of diarrhoea during cancer chemotherapy. Lancet Oncol. 2014;15:e447-60. doi: 10.1016/S1470-2045(14)70006-3.

6. Benson AB, Ajani JA, Catalano RB, Engelking C, Kornblau SM, Marteson JA Jr, et al., Recommended Guidelines for the Treatment of Cancer Treatment-Induced Diarrhea. J Clin Oncol. 2004;22:2918-26.

7. Muls AC, Lalji A, Marshall C, Butler L, Shaw C, Vyoral S, et al. The Holistic Management of Consequences of Cancer Treatment by a Gastrointestinal and Nutrition Team: A Financially Viable Approach to an Enormous Problem? Clin Med. 2016;16:240-6

8. Larsen HM; Borre M; Christensen P; Drewes AM, Laurberg S, Krogh K, et al. Clinical Evaluation and Treatment of Chronic Bowel Symptoms Following Cancer in Colon and Pelvic Organs. Acta Oncologica. 2019;58:776-81. 
9. Ozorio GA, Barão K, Forones NM. Cachexia Stage, Patient-Generated Subjective Global Assessment, Phase Angle, and Handgrip Strength in Patients with Gastrointestinal Cancer. Nutr Cancer. 2017;19:1-8.

10. Faramarzi E, Mahdavi R, Mohammad-Zadeh M, Nasirimotlagh B. Validation of Nutritional Risk Index Method Against Patient Generated Subjective Globa Assessment in Screening Malnutrition in Colorectal Cancer Patients. Chin. F. Cancer Res. 2013;25:544-8.

11. Rezaie A, Pimentel M, Rao SS. How to Test and Treat Small Intestinal Bacterial Overgrowth: An Evidence-Based Approach. Curr Gastroenterol Rep. 2016; 18:1-11

12. Rao SS, Tan G, Abdulla D, Yu S, Larion S Leelasinjaroen P. Does Colectomy Predispose to Small Intestinal Bacterial (SIBO) and Fungal Overgrowth (SIFO)? Clin Transl Gastroenterol. 2018;9:146. doi: 10.1038/s41424-018-0011-x.

13. Muls AC. Gastrointestinal consequences of cancer treatment and the wider context: A bad gut feeling. Acta Oncol. 2014;53:297-306.

14. Friedrich DC, Santos EB, Ribeiro-dos-Santos AKC, Hutz MH. Several Differen Lactase Persistence Associated Alleles and High Diversity of the Lactase Gene in the Admixed Brazilian Population. PLoS One. 2012;7:e46520.

15. Ji J, Sundquist J, Sundquist K. Lactose Intolerance and Risk of Lung, Breast and Ovarian Cancers: Aetiological Clues from a Population-Based Study in Sweden. Br J Cancer 2015;112:149-52.

16. Kim JW. Lactose Intolerance and Colorectal Cancer. Ann Coloproctol. 2017;33:157-8

17. Common Terminology Criteria for Adverse Events (CTCAE) Version 5,0. U.S Department of Health and Human Services. 2017. Available from: https://ctep. cancer.gov/protocolDevelopment/electronic_applications/docs/CTCAE_v5 Quick Reference 8.5x11.pdf

18. Lewis SJ, Heaton KW. Stool Form Scale as a Useful Guide to Intestinal Transit Time. Scand J Gastroenterol 1997;32:920-4.
19. Losurdo G, Leandro G, Ierardi E, Perri F, Barone M, Principi M, et al., Breath Tests for the Non-invasive Diagnosis of Small Intestinal Bacterial Overgrowth: A Systematic Review With Meta-analysis. J Neurogastroenterol Motil. 2020;26:16-28.

20. World Health Organization. Obesity: Preventing and Managing the Global Epidemic: Report of WHO Consultation on Obesity. Geneva. WHO. 1997, 178p.

21. Lipschitz DA. Screening for Nutrition Status in Elderly. Prime Care. 1994; 21:55-67.

22. Schmoll HJ, Cartwright T, Tabernero J, Nowacki MP, Figer A, Maroun J et al., Phase III Trial of Capecitaine plus Oxaliplatine as adjuvante therapy for Stage III Colon Cancer: A Planned Safety Analysis in 1864 Patients. J Clin Oncol. 2007;25:102-9.

23. Glynne-Jones R, Dunst J, Sebag-Montefiore D. The integration of oral capecitabine into chemoradiation regimens for locally advanced rectal cancer: how successful have we been? Ann Oncol. 2006;17:361-71.

24. Brägelmann R, Armbrecht U, Rosemeyer D, Schineider B, Zilly W, Stockbrügger W. Small Bowel Bacterial Overgrowth in Patients After Total Gastrectomy. Eur J Clin Invest. 1997;27:409-16.

25. Newberry C, Tierney A, Pickett-Blakely O. Lactulose Hidrogen Breath Test Result is Associated with Age and Gender. Biomed Res Int. 2016;2016:1064029.

26. Saffouri GB, Shields-Cutler RR, Chen J, Yang Y, Lekatz HR, Hale VL, et al. Small Intestinal Microbial Dysbiosis Underlies Symptoms Associated with Functional Gatrointestinal Disorders. Nat Commun. 2019;10:1-11. https://doi.org/10.1038/ s41467-019-09964-7.

27. Liang S, Xu L, Zhang D, Wu Z. Effect of Probiotics on Small Intestinal Bacterial Overgrowth in Patients with Gastric and Colorectal Cancer. Turk J Gastroenterol. 2016;27:227-32.

28. Osterlund P, Ruotsalainen T, Peuhkuri K, Korpela R, Ollus R, Ikonen M, et al. Lactose Intolerance Associated with Adjuvant S-Fluourouracil-Based Chemotherapy for Colorectal Cancer. Clin Gastroenterol Hepatol 2004;2:696-703. 